\title{
Boots Book-lovers' Library and the novel: The impact of a circulating library market on twentieth-century fiction
}

Article

Wilson, N. (2014) Boots Book-lovers' Library and the novel:

The impact of a circulating library market on twentieth-century fiction. Information and Culture: A Journal of History, 49 (4). pp. 427-449. ISSN 2164-8034 doi:

https://doi.org/10.7560/ic49402 Available at https://centaur.reading.ac.uk/31358/

It is advisable to refer to the publisher's version if you intend to cite from the work. See Guidance on citing.

Published version at: http://utpress.utexas.edu/index.php/journals/information-culture

To link to this article DOI: http://dx.doi.org/10.7560/ic49402

Publisher: University of Texas

All outputs in CentAUR are protected by Intellectual Property Rights law, including copyright law. Copyright and IPR is retained by the creators or other copyright holders. Terms and conditions for use of this material are defined in the End User Agreement.

www.reading.ac.uk/centaur 
Central Archive at the University of Reading

Reading's research outputs online 
Boots Book-lovers' Library and the novel: The impact of a circulating library market on twentieth-century fiction

Nicola Wilson

University of Reading

Department of English Literature

Whiteknights

University of Reading

Reading

RG6 6AH

n.l.wilson@reading.ac.uk

This is the final author-copy of an article published in Information and Culture 49.4 (Nov/Dec 2014), 427-49.

This version is under a 12 month embargo period as agreed with the publisher of the journal until Nov/Dec 2015. 


\section{Boots Book-lovers' Library and the novel: The impact of a circulating library market on twentieth-century fiction}

"It is increasingly apparent that, for better or for worse, we have become a nation of bookborrowers" (F.R. Richardson, "The Circulating Library," 1935) ${ }^{1}$

In 1935, F.R. Richardson, head of Boots Book-lovers' Library, contributed an essay on "The Circulating Library" to a volume featuring the great and the good of the contemporary book world. In the book's introduction, Stanley Unwin, President of the Publishers' Association, lamented the fact that the "New Reading Public" were not on the whole buying books despite the proliferation of cheap series in the market and the wide availability of books at three shillings and sixpence (3s. 6d.), "and still more often 2s.", "Books are the last thing most people have any intention of buying, or can ever be persuaded to buy," wrote Unwin. ${ }^{3}$ This was in many ways a familiar cry from the publishing and bookselling industry, but the effects of increased library borrowing and the role of private, circulating libraries in Britain in the first half of the twentieth century have often been overlooked in literary and cultural analyses and histories of reading. This essay seeks to redress this through an examination from publishers' archives of how the Boots Book-lovers' Library market impacted editorial policy, literary marketing and censorship, and authors' practices of writing and revision. It focuses in particular on the editing and revision of the Irish writer James Hanley’s (1897-1985) 1935 novel, The Furys. ${ }^{4}$

The significance of commercial circulating library readers to the history of the novel in Britain in the twentieth century, at least up until the Second World War, is not widely known. The general supposition that the power of the circulating libraries waned with the

"death" of the three-volume novel form at the end of the nineteenth century - a form that the circulating libraries and their readers had sponsored and supported - has led to an underestimation of the impact of the more recent private library market. ${ }^{5}$ For instance, in The Haunted Study: A Social History of the English Novel 1875-1914, Peter Keating describes the weakening power of the circulating libraries in the early twentieth century in the face of divergent methods of literary publishing (particularly the growth of little magazines) and the rapid growth of public libraries. ${ }^{6}$ Nickianne Moody, who has conducted oral history research on the Boots Book-lovers' Libraries, writes that "in terms of historical narrative, the interwar commercial libraries in particular did not hold the same power over writers and publishers which was enjoyed by the nineteenth century subscription libraries such as Mudie's Select 
Circulating Library and has been the subject of academic consideration."7 But this historical narrative belies the increasing popularity of private, fee-paying libraries like Boots (18991966) and W.H. Smith (1860-1961) in the first half of the twentieth century, as well as the significance of their market share to the publishing industry and the willingness of publishers and authors to bear the likely responses of their readers in mind.

\section{Boots Book-lovers' Library and the twentieth-century circulating library market}

The commercial circulating library market expanded rapidly in the first half of the twentieth century. Boots Book-lovers' Library, established in 1899 by Florence Boot (wife of Jesse Boot, the chemist), was one of several new commercial libraries formed to capitalize upon the growth in reading - and especially fiction - as a pastime by an increasingly wide section of the public. It operated, as did Mudie's Select Circulating Library (established 1842) and the libraries of W.H. Smith, by membership subscription. Readers were able to borrow any volume in circulation ("on demand"), all newly published books, or all but the newest books, according to the subscription rate they paid. Books could be exchanged at any branch across the country if the reader wanted a more expensive "travelling" subscription; on a cheaper package they were to be exchanged at one branch only. Principles of distinction, selection, and taste were paramount, and the library prided itself on the attractiveness and "hygiene" of its books and the ambience of its branches. A 1920 catalog outlining some of the advantages of library subscription notes that "Our methods in this direction have been

described as the last word in Library construction". ${ }^{8}\left[* *\right.$ Author's note $n_{\underline{-}} \mathrm{b}_{\underline{-}}$ typesetter - bold in original - please remove after setting*] 


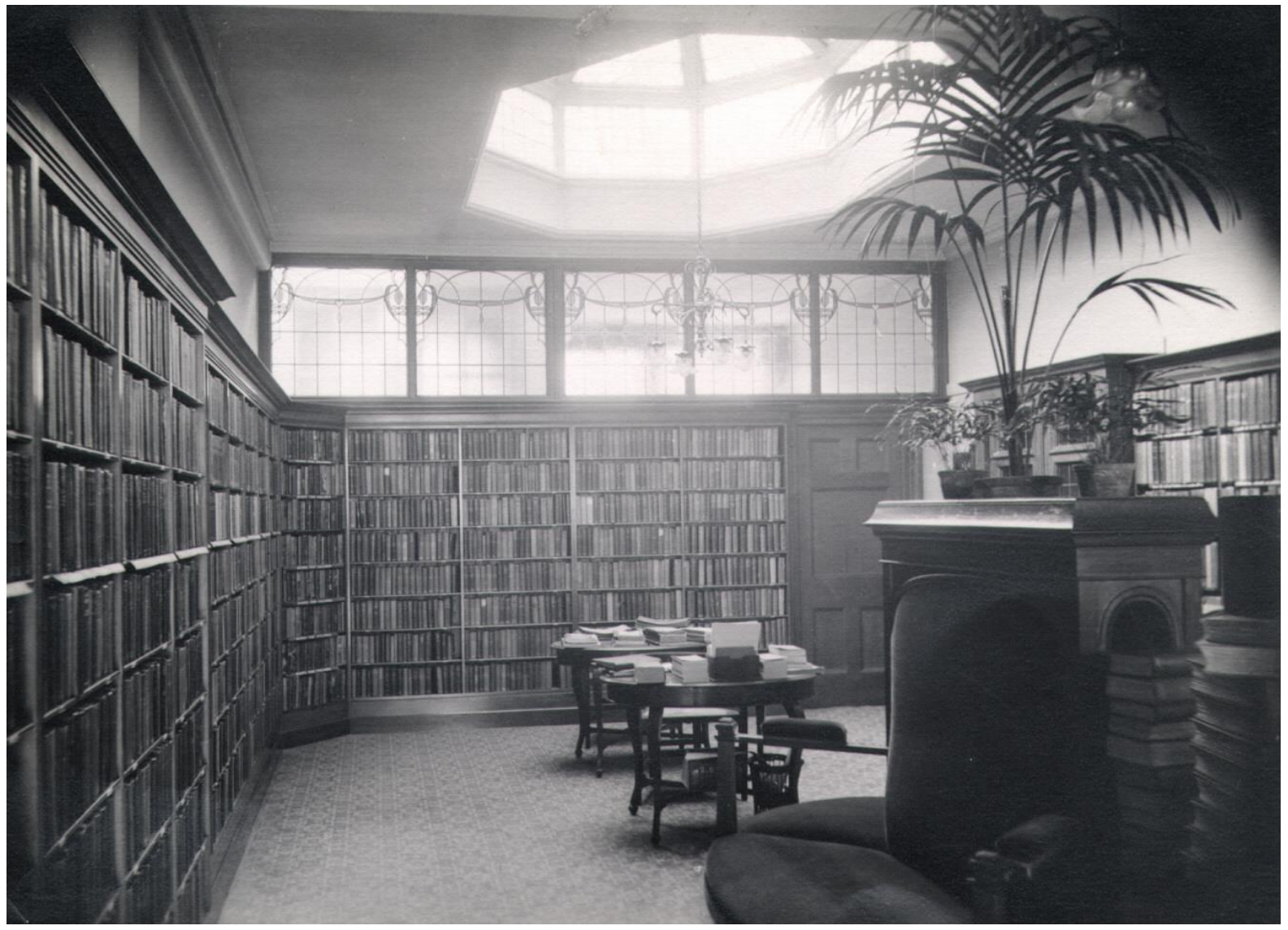

[insert fig. 1] "The last word in Library construction," Boots library branch, Brighton store, 1929. Reproduced with thanks to The Alliance Boots Archive \& Museum Collection.

The Boots Book-lovers' Library service grew rapidly so that between the end of the First World War and its ultimate demise in 1966 it was the largest of what the publisher Harold Raymond referred to as the "big noises." In 1920 Boots had over 200 libraries in Britain attached to their high-street pharmacies; by 1938 there were 460 branches. Membership increased during both World Wars reflecting the loss of other leisure activities and the turn to reading (and in particular light fiction) during wartime, and while smaller library branches continued to make a loss, Boots expanded its library service to more of its stores throughout the Great Depression. By the end of the Second World War, they had over a million subscribers, and in 1950, when its operations were comparable only to W. H. Smith, it was issuing approximately 50,000,000 volumes a year. Boots's libraries absorbed the stock of Mudie's when the latter collapsed in 1937 and subsequently that of rival W. H. Smith when their library service closed down in 1961. It was the sole surviving major nationwide 
circulating library when the last of its remaining 121 branches were finally closed down in February 1966.

The Boots libraries were primarily designed to attract shoppers into the stores and to cultivate loyalty and good customer relationships. As Richardson, the head librarian, noted to library colleagues in Boots's in-house magazine, The Bee (Be Enthusiastic Efficient), in 1922, "ours is not the selling side of the business, but we have charge of something equally as important, and that is service. The Library service makes customers for the general business, and having made them, our business is to keep them."10 The patrons of Boots comprised part of the "New Reading Public" described by the newspaper editor Sidney Dark in a lecture in 1922 as "that ever-increasing company drawn from what we commonly call the lower middle class and the working class, who have discovered that the literature of their country is a priceless possession which is their very own." ${ }^{11}$ In 1920, a reader opting for the cheapest "Home" subscription at Boots, which entitled them to borrow all but the newest books from one library (one volume at a time), paid ten shillings and sixpence (10s. 6d.) a year. This represented good value for money to the potential book-buyer when the cost of one long newly-published novel could reach 10s. 6d. (the majority were 7s. 6d.). Yet in answer to the constant charge from booksellers that the circulating libraries were damaging the sale of books, Richardson argued that their libraries catered to a different reading audience. This was the great middling classes, those who were reluctant to rub shoulders with working men and women in the free public libraries but who would not necessarily buy books from a bookshop. "Surely the majority of its borrowers are people who would never pay seven shillings and sixpence for a new novel," he wrote, "who would rarely buy books in any case, and who would surely read far fewer books, instead of buying more, if the libraries were swept out of existence."12

Unlike Smith's, whose railway bookstores and libraries were seen to cater to a more genuine cross-section of the population, Boots cultivated a reputation for patrons of the middle class. ${ }^{13}$ The image of the Boots subscriber passed down in the cultural record is defined by two prominent representations of female middle-class readerships. Laura Jesson, the heroine of Brief Encounter (1945) and Still Life (1935) (the Noel Coward play upon which the film is based), borrows books from Boots on her weekly shopping trips into town. As Nicola Beauman has pointed out in her reading of the women's novel between the wars, this excursion is the highlight of Laura's week, and Coward's naming of Boots is meant to signify the particular type of domestic middle-class existence pertaining to "a respectable married woman with a husband and a home and three children." ${ }^{14}$ In a contemporaneous 
work, The Death of the Heart (1938) by the Irish novelist Elizabeth Bowen, Boots Booklovers' Library is satirised as "Smoot's" where in a hot and dusty upstairs room the "heating drew out a gluey smell from the books . . . In all senses, literature was in bad odour here."15 The librarian, Daphne, is sufficiently haughty to impress the elderly lady subscribers who feel compelled to choose belles lettres rather than the new-looking novels they actually desire. The subscribers are mocked by Bowen as a "clientele of discarded people . . . who could expect no more from life, and just dared to look in books to see how much they had missed."16

The historical accuracy of these portrayals is now difficult to quantify, though they are certainly caricatures. The Boots company archive in Nottingham has a small collection of material relating to the library business (including catalogues, some members' book lists and borrowing cards, publicity material, in-house training advice to librarians and financial records), but there are no known surviving borrower records that would enable the kind of large-scale empirical and statistical research into readers and reading patterns as undertaken by Mary Hammond in her work on British public libraries or by researchers at Ball State University in the recent database project, "What Middletown Read." 17 A cartoon depicting "Our Customers" in The Bee from April 1922 depicts twelve types of people who constitute "that vast multitude which comes to our counters." 


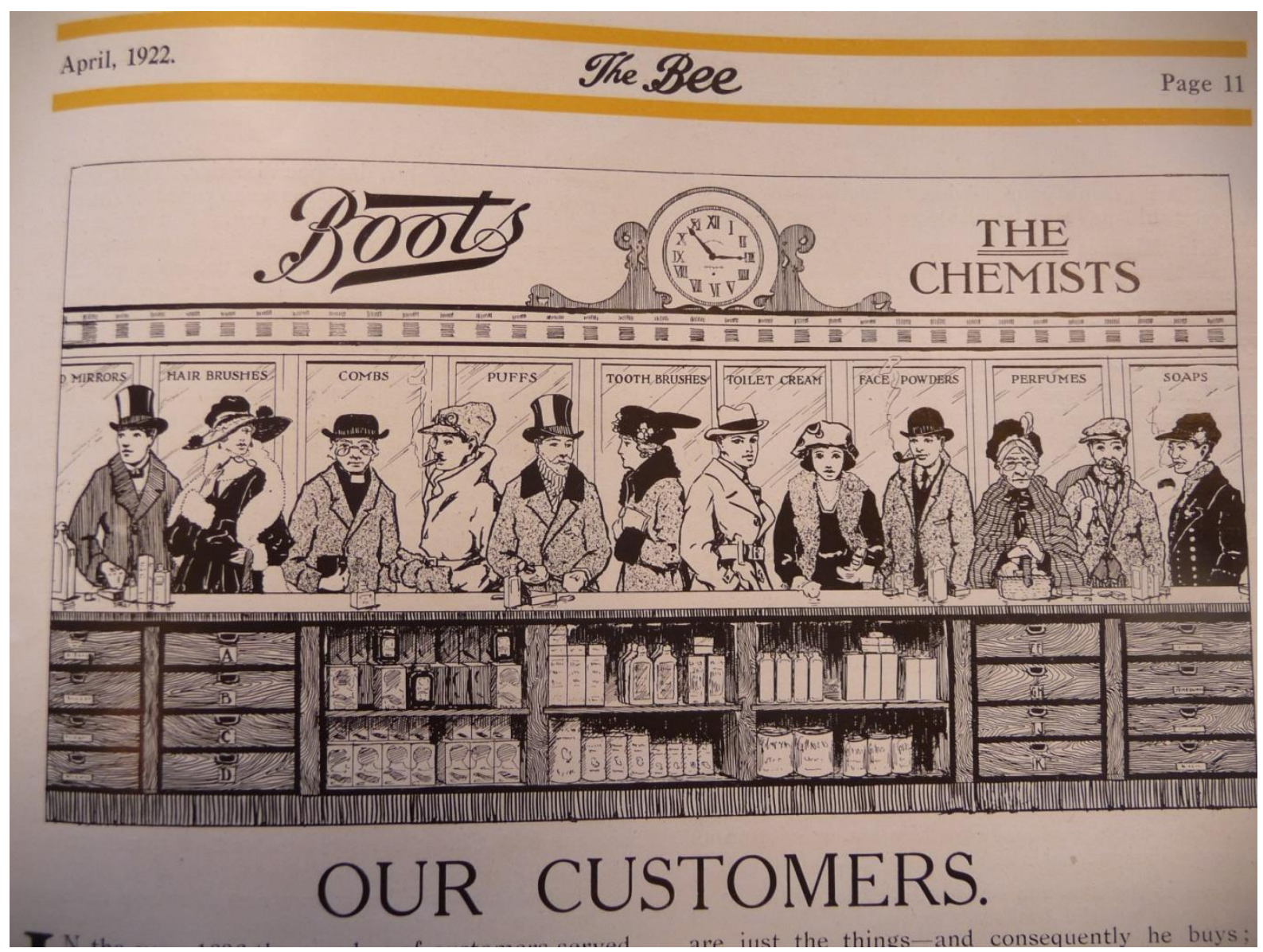

[insert fig. 2] The Chemists and library patrons. 'Our Customers' in The Bee, April

\section{Reproduced with thanks to The Alliance Boots Archive \& Museum Collection.}

According to this article, Boots's high-street stores had in the preceding year served over eighty-eight million people. This ranged from the "people who give you an impression of affluence" to "His Highness, the Pearly King," with "the business gentleman about town," "the average housewife" and "the old lady whose life has been full of experience, but whose purse has never been correspondingly full" ranking somewhere in between. ${ }^{18}$ With the lowest annual subscription remaining at 10s. 6d. up until the mid 1930s - when borrowing was made cheaper and more flexible with a non-subscription 'Pay as you read scheme' designed to compete with the increasingly popular twopenny libraries and the restrictions of the economic depression - only a limited proportion of these social types would have been able to patronise the library counters. The lowest rate of yearly subscription, $10 \mathrm{~s}, 6 \mathrm{~d}$., was equivalent to a week's rent for many working-class people who would instead have borrowed books from the free public libraries, self-help groups like the Co-operative Society, or the local twopenny libraries attached to stationers and tobacconists. ${ }^{19}$ 
The gender make-up of Boots subscribers is still assumed to be largely female. Rowntree and Longmans's study of reading patterns in Boots's and Smith's libraries in the early 1950s found that "women account in each case for some seventy percent of customers, but a proportion of them are almost certainly borrowing books for their husbands or male relatives to read." 20 The historical association of female readers with circulating libraries is well established, going back to the campaign against what the novelist George Moore described as the "circulating morals" of the subscription libraries in the late nineteenth century. ${ }^{21}$ The illustrations and photographs in Boots's publicity material portray a largely mixed readership, with images appealing equally to the "discerning" gentleman reader and the budget-conscious housewife ("do you know how little it costs to borrow good books?" asks one leaflet). ${ }^{22}$ A flyer from the early 1940s refers to reading as "One Black-Out Benefit," depicting the fireside reading of husband and wife during "the long winter evenings at home. ${ }^{, 23}$ In her oral history research on the Boots Book-lovers' libraries, Nickianne Moody points out that "librarians and subscribers do not remember Boots necessarily as a gendered library serving only the woman reader," but that the "model of librarianship and the physical, almost domestic, space of the library" was clearly meant to appeal to a female middle-class clientele. ${ }^{24}$ In the Boots Book-lovers' Library's "First Literary Course," an inhouse training guide for librarians produced after the Second World War, there are constructions of typically gendered reading patterns, with suggestions that women are "inclined towards the domestic or personal type of detective stories, and men to the more realistic sort." Women will, according to Boots, "often take their literature of relaxation in a gentler form than men do and prefer tales of romance or about families to murder yarns. $" 25$

The growth of Boots as one of the major commercial libraries in the first half of the twentieth century must be seen in context of the simultaneous growth of the public library movement in Britain. While there has been some suggestion that the public libraries overtook the subscription libraries as one of the main purchasers for books in the early part of the twentieth century, this in fact happened much later, from the late 1950s through to the 1970s. Public libraries, founded for educational reasons, were notoriously reluctant to purchase new novels in any large numbers and did not buy the work of contemporary authors in bulk in the way that the business model of the circulating libraries demanded. For instance, records in the archive of the London-based wholesaler Bumpus Booksellers (which provided books to public libraries across the country) indicate that many of the new free libraries established in the early decades of the twentieth century were mainly buying novels of popular Victorian authors like Wilkie Collins, Mary Elizabeth Braddon and Marie Corelli: novelists whose 
works were cheaper, still popular, and, for oftentimes cautious Public Library Committees, "tried and tested." Many Public Library Committees sought to purchase books second-hand wherever possible and would only occasionally select contemporary titles from a parcel of "up-to-date novels." ${ }^{26}$ While the actions of the public libraries with regards to the banning of certain books (like H.G. Wells's Ann Veronica (1909)) may have caused a stir, they were not a primary purchaser of the mass of fiction produced during the first half of the century. There is scant evidence in correspondence between publishers and authors to suggest that they were thinking about the tastes or demands of public library readers when they were publishing or marketing their books.

The commercial circulating libraries like Boots and Smith, on the other hand, were compelled to buy-in enough copies of newly published novels to circulate throughout the stores and to satisfy their readers' demands for the latest in new and contemporary fiction. The business model was cumbersome and liable to create losses, and the circulating libraries' regular book sales of stock constituted a significant part of their income. But for publishers this meant that the circulating libraries remained one of the key primary customers for the new books they were producing throughout the first half of the twentieth century. In a report for the Society of Bookmen in 1928, publishers estimated that between a quarter to twothirds of all the books they published went to the big four circulating libraries (Boots, Smith, Mudie's and The Times Book Club), where over eighty percent of the books in demand was said to be fiction. ${ }^{27}$ The impact of the libraries and their paying readers as harbingers of taste and literary fortune could therefore be profound.

\section{Boots Book-lovers' Library and the novel}

According to the popular novelist Winifred Holtby, the circulating library public was "the great intermediate class of the 'novel reading public' who read the large and ever increasing body of competent works of fiction." ${ }^{28}$ The libraries of Boots and Smith are indelibly linked with the popular and the middlebrow and continue to be tainted by the intellectual snobbery associated with those terms. To the cultural critic Q.D. Leavis, for instance, who had spent "many hours at different branches" of Smith and Boots as part of her research, the circulating library public had "acquired the reading habit while somehow failing to exercise any critical intelligence about its reading." ${ }^{29}$ Yet reading the Boots library catalogs and in-house training guides provide an important corrective to the academic narrative of literary history, something which recent research on the literary middlebrow has also sought to dislodge. ${ }^{30}$ The names which emerge in the literature from Boots remind us of popular authors and texts 
that are now overlooked, such as Gilbert Frankau (1884-1952) whose post-war novel Peter Jackson, Cigar Merchant: A Romance of Married Life (1920) was "undoubtedly the Best Seller of the year" and A.S.M. Hutchinson's (1879-1971) hugely popular If Winter Comes (1922). ${ }^{31}$ Discussing the "over-production" of books in 1935, Richardson, Boots's head librarian, noted the exceptions:

The works of such a writer as Hugh Walpole go on for ever; and so, too, do some pleasant novels (those of Elizabeth Carfrae, for instance) which have never been trumpeted in any quarter, but have the most effective and persistent of all advertisements - friendly recommendation from one to another of that great majority of readers who are seeking only good recreation, and care nothing about being au fait with "the book of the moment." 32

This typifies the Boots library's attitude to reading: stressing the importance of good service and "friendly recommendation," while seeking to legitimise the tastes of its readers in a deliberately cavalier tone. The juxtaposition of Carfrae and Walpole stresses Boots's uneasy positioning between the lowbrow and the middlebrow. Elizabeth Carfrae was a bestselling novelist of romantic fiction, published by the "library house" publishers Mills \& Boon. ${ }^{33} \mathrm{Her}$ work was marketed aggressively and headed Mills \& Boon's new series of "Popular 2/6 novels" in the late 1920s, a series which attempted to take advantage of the lower end of the book market through the potential of cheap, mass sales. Hugh Walpole (1884-1941), on the other hand, was a longstanding Macmillan author and well known in the 1930s for his historical family saga of the Herries. These were long novels, designed to impress their importance upon the public and, like The Furys, first sold at 10s. 6d. Walpole represented Boots Book-lovers' Library's pretensions to be a library of serious literature, and not only the "pleasant" and popular like Carfrae. The library had to stock what its readers wanted to read (this of course is the service they paid for), but there was nevertheless a constant emphasis in the library business towards "developing" the tastes of its readers (similar to that found in public libraries of the time). "Public taste is to be greatly credited for its interest in the works of such men as Sir Hugh Walpole, H.G. Wells, Charles Morgan, Aldous Huxley and Winston Churchill” notes Boots's post-war training course for librarians on "Best Sellers." "[T]he reading public is considerably better educated today than it was in the early part of the century." 34 
As one of the major purchasers and distributors of new novels, the circulating library market had long affected the form and content of the novel, and this continued until the end of the Second World War. Surviving records in publishers' archives like those of Chatto \& Windus reveal how the perceived tastes of the circulating library market could guide publishing and editorial decisions. Chatto \& Windus (founded in 1853) was not a so-called "library house" publishing "light fiction" like the modern publishers Herbert Jenkins (founded 1912) or Mills \& Boon (established 1909). ${ }^{35}$ According to Boots's "First Literary course," in fact, Chatto was a publisher of "good fiction, literary criticism, and biography," an indication of this being their publishing of "Compton Mackenzie, Sylvia Townsend Warner, Aldous Huxley and E.M.W. Tillyard." ${ }^{36}$ But the advance subscription orders and sales to commercial libraries like Boots represented a key part of Chatto's distribution network and were understood to signify the tastes of the general reader and the wider book world as a whole. Records in the Chatto archive demonstrate how the publisher would often report advance sales to authors solely through reference to the numbers purchased by the circulating library market. Thus the likely tastes of commercial library readers were born in mind throughout the publishing process. In a revealing letter to the author Mary MacCarthy (1882-1953), for example, Chatto's editors describe how they have read the manuscript for her first novel, A Pier and A Band (1918), "with very great appreciation of its delicacy and subtlety," but that they are not hopeful for its prospects "as a commercial speculation." The letter reveals how the perceived tastes of the circulating library market clearly influenced editorial decisions:

At the same time we should like, if we may be allowed to do so, to warn you that in its present form the story is not likely to stimulate a wide interest among typical library subscribers. It is too quiet, and in our opinion it is too undramatic, to do this. We even think that it would be an advantage in other respects to introduce some occasional compression and to deepen - if that were possible - the reader's sense of the conflict in progress throughout the book. ... That conflict is apparent, and to an attentive reader it is amply suggested by many delicate passages; but we believe the book may run the risk of being thought uninteresting by those who ascribe that defect to any work that is unemphatic in character. ${ }^{37}$ 
Responding to the Commercial Circulating Libraries Sub-Committee in 1928, publishers stated that commercial libraries affected the length, format, and marketing of books. For instance they apparently "resisted the purchase of books bound in certain colours easily spoilt by rain." 38 Titles were to be short and snappy. Chattos advised the Anglo-Indian novelist Fanny Emily Farr Penny (1847-1939) that "Missing" was a better title than "The Ranee's Private Secretary" as "it is rather long, and I am not sure whether it has sufficient 'grip' to attract library readers." 39 In May 1937, Harold Raymond wrote to the bestselling novelist Ann Bridge (Mary Dolling O’Malley) (1889-1974), to advise her to “chop out some of the foreign phrases" in her Italian novel, Enchanter's Nightshade (1937). Raymond's suggestion was apparently disingenuous. Part of the popular appeal of Ann Bridge's romantic historical fiction was her sensitive and carefully researched depictions of foreign cultures (as in her first hugely successful novel, Peking Picnic (1932)), for which she drew on her own experience as a diplomat's wife overseas. Nevertheless, the publisher felt that the amount of Italian used in Enchanter's Nightshade was likely to "frighten" many readers and particularly the all-important patrons of Boots: "I remember chuckling at this comic affectation of lowbrowism, yet I believe that that is the genuine reaction of thousands of Boots subscribers. If they pick up a book off the library shelf and find it bespattered with italicised foreign words they are apt to funk it." The publisher's perception of the general novel-readers' parochialism was shared in the in-house advice given to Boots's librarians, who were warned to avoid recommending books containing dialect to their "lowerbrow" subscribers: "the reader is not prepared to accept anything unfamiliar and the people she is concerned with must use her own language."

If editorial suggestions concerning character, style, and language, as well as the look of a book and its title are one indication of the impact of the circulating library market on the writing and production of fiction in this period, the question of where this slips into censorship is complex and is explored more fully in the case study on James Hanley below. In terms of the more tangible matter of the circulating libraries' role in censoring the circulation and distribution of new books, the 1928 Society of Bookmen report found that "[n]o evidence on the subject of the censorship of books by the libraries has been offered." This was a notoriously problematic, not to say secretive, area. As the authors of the report explained:

Probably, however, the libraries would disclaim the exercise of [such] power, but they are liable to simultaneous complaints from both sides: some of their clients objecting 
to certain books being freely circulated, whilst others object even more strongly to the same books not being circulated. ${ }^{41}$

The circulating libraries navigated their way around this bind by carefully limiting the circulation of books that were likely to offend the majority of their subscribers. The practice of "stocking but not circulating" a book was a form of covert censorship practised by the libraries that was meant to prevent the easy distribution of a book that was in their eyes controversial, but not necessarily considered legally obscene or worthy of an outright ban. A book that was "stocked but not circulated" was not allowed onto the open shelves and was issued to readers only on request. In Boots, these volumes were marked with a red label and a small pool was held at the Head Office. Librarians were instructed that if a Class " $A$ " subscriber (who paid to receive all books in circulation at the library) had requested titles on their Book List other than a Red Label volume, then the latter needn't be ordered. Internal documents in the Boots archive from the late 1930s through to the 1950s make clear the continued operation of classificatory schemas and the secrecy involved in the library's vetting practices:

Red Label . . . items must not be shown to subscribers, nor must the significance of these labels be explained; these internal regulations are private and must not be explained to the public. Red Label ... volumes must be supplied only when the specific titles is ordered. ${ }^{42}$

\section{The Boots subscriber and James Hanley's The Furys (1935): a case study}

Some of the most revealing correspondence in the Chatto \& Windus archive concerning the Boots library reader involves the debate between the publisher Harold Raymond and the Irish working-class novelist, James Hanley, regarding the publication of his novel The Furys. This was the first of a pentalogy of novels centring upon an Irish working-class family living in Liverpool (published between 1935 and 1958). ${ }^{43}$ Hanley was a merchant seaman who for much of the 1920s had worked as a railway porter in Bootle, north of Liverpool. He had been introduced to Chattos's Charles Prentice by the author David Garnett, but Chattos had rejected Hanley's early novels, including Drift (published by Eric Partridge's Scholartis Press in February 1930), and his infamous 1931 novel, Boy. ${ }^{44}$ Hanley had long sought to come under the imprint of a respectable literary publishers like Chattos. When in January 1935 he received a sample copy of The Furys (the first book that he published with them) he wrote 
that he was "well pleased with it. I liked it very much, and of course got a sort of kick out of seeing 'Chatto \& Windus' on my title pages at long last.",45

By the time Hanley signed a contract with Chattos in May 1934 (he was contracted to them for at least his next four books) he had a reputation as an important and serious novelist, and was celebrated by parts of the Left as a budding working-class writer. In November 1934 for instance a substantial extract from The Furys was serialised in The Left Review, the flagship journal of the Popular Front. He had some powerful literary champions including the contemporary British writers Storm Jameson, Richard Aldington, E.M. Forster and John Cowper Powys, the latter of whom compared his style to that of James Joyce. The American rights for The Furys were readily snapped up by Macmillans. Yet Hanley's work also divided the reading market. In a series of letters received from libraries and booksellers in response to the advance copies of The Furys that Chattos sent out to the book trade, we can see the kind of fissures his work produced. As one bookseller and circulating library in Newcastle, Mawson Swan \& Morgan, asked:

Is not this the author who wrote a book called "Boy", which was too strong for most people? At least so I heard from our Library Department.

As soon as I have finished The Furys I shall send it to our New Book Department, because it is a book we ought to know about and it does us good to sell a book of this nature, which is so far and above the average 7/6 novel.

Alan Steele of The Times Book Club declared, "I do hope that this book will establish him at last." There is also an interesting note in the Chatto files from Boots Book-lovers' Library's head office signed by F.R. Richardson: "Undoubtedly this author is destined for the high light's and I shall try to read this book myself.",46

Chattos had to tread a fine line with Hanley's work and their reading of The Furys clearly indicates their cautious response to its likely reception. In a long letter to Hanley dated July 11, 1934, detailing his first impressions of reading the manuscript ("I like it immensely,") the publisher urged censorship of the novel's "bad" language. Fearing the possibility of prosecution for Hanley's frequent use of the word "bugger" - " "the word of endearment chiefly used amongst sailors' (I forgot whose definition that was,") Raymond wrote - the publisher urged Hanley to omit it altogether (it is used 16 times in the manuscript), along with other swear words like "shit" and "arse." The request for omission is 
directly related to the anticipated response of the circulating library audience as the primary market for newly published works of fiction:

I have no personal feelings whatever on the subject, but I have discussed the problem with the travellers, booksellers and circulating librarians and they are all of one opinion, that the circulating library public as a whole jibs at the word, and that its inclusion would materially decrease your sales, leading if not to an actual banning of the book by Boots etc, at any rate to a ca'canny distribution of it. Incidentally also, it would almost certainly involve the book being banned in the Free State [Ireland], where otherwise it ought to sell well . . [I]t seems to me that this book has got a real chance of enhancing your reputation and materially increasing your sales. But the latter cannot be achieved without some concessions to the timidities and prejudices of the average Boots subscriber. ${ }^{47}$

Raymond reveals here how a book's being branded a Red Label title and given a "ca-canny" (deliberately limited) distribution through the practice of "stocking but not circulating" it, caused a negative impact upon sales and an author's reputation at home and abroad. Still struggling financially and having long fought to get his work into print, Hanley was realistic about the requested "concessions." He replied that "The book is the thing, and not a few words like bugger ... No I am entirely agreed upon the deletion of those words which would no doubt touch tender spots like Times Book Club etc etc." ${ }^{48}$ Hanley was aware that his work presented difficulties for publishers and libraries. In an attempt to bypass the censor, the trade edition of Boy had been published by Boriswood in an expurgated form whereby single words, phrases, complete sentences and paragraphs had been replaced by asterisks. In the cheap edition, published in May 1934, the expunged passages were replaced by milder words, and Hanley suggested some of these alternatives in the editorial correspondence with Raymond regarding The Furys.

While Hanley was ready to make concessions over the novel's language, he rejected the publisher's questioning of the novel's gothic character, Professor Titmouse. According to Raymond the character of Titmouse was " $[\mathrm{s}]$ omehow . . . out of keeping with the rest of the book, too grotesque and fantastic." 49 Questioning the character's role and function in the plot and offering advice on characterisation, Raymond wrote again a few days later: "it might be worth your while reconsidering his introduction to the reader and seeing if by very slight alterations you might make him a little more substantial to begin with. So far, he strikes us as 
being a trifle phantasmagoric." ${ }^{50}$ Hanley was intransigent and insisted that the mad Professor couldn't be deleted, before he finally tried to explain the episode in more detail:

My opinion is this, and it has not altered since I introduced that character, that his phantasmagorical appearance and vanishing gives that chapter the very queerness I wished to give it. Moreover the very scenes in that chapter in my mind have a sort of spectral atmosphere, and identical one for such a man. At the same time it does not follow that this character should not reveal himself later on in flesh and blood. But if he appears like that in this volume then the queerness I aimed at in that chapter is lost. It is enough that he enter and disappear in that queer way. ${ }^{51}$

The issues at stake in this debate between author and publisher over a "spectral" character revolved around the likely response of what Holtby had identified as "the great intermediate class of the "novel reading public"" to an eerie, grotesque and sexually dubious episode in what was marketed as a predominantly realistic saga of working-class family life. The "queerness" of the Professor's appearance in the strike scene refracts the reader's and the young ingénue Peter's experience of the crowd through the misanthropic, alienating vision of the older man, from whom there is a clear implication of sexual threat:

The peculiar noise the man made, almost like the gobble of a turkey, the click of his tongue, made him feel physically sick, as the other evening his grandfather's slobbering had done when he had had to feed him. Now he wanted to vomit. He closed his eyes. The professor had leaned forward again, so that the boy could feel his breath upon his face. ${ }^{52}$

The publisher's doubts about characterisation and the Professor's appearance in the strike scene are clearly tied up with a more general anxiety about homosexual rape in Hanley's work. The scene between Peter and the sinister Professor recalls scenes of a similar nature in Hanley's earlier controversial novels, Boy and The German Prisoner (published privately in 1930). ${ }^{53}$

Hanley's rights as author of the work were respected in this exchange, and "concessions to the timidities and prejudices of the average Boots subscriber" were made only with respect to the manuscript's swear words and not to the sexually ambiguous depiction of Peter and the Professor atop the stone lion. Interestingly, while the representation 
of the strike was sufficiently opaque as to frustrate reviewers as to the historical situatedness of The Furys (there was debate as to whether it was set during the General Strike of 1926, the Great Liverpool Transport Strike of 1911, or the large demonstrations of the Liverpool unemployed and their brutal suppression by the police in 1921-22), few contemporary reviewers questioned the "queerness" of the strike scene itself. Instead, the novel with its dust-cover "disclosing a slum street, a dockyard and a group of men with their hands fast in their pockets" was readily subsumed within the contemporary genre of "social problem" novels, and compared with Walter Greenwood's Love on the Dole (1933), Phyllis Bentley's Inheritance (1932), and James Hodson's Harvest in the North (1934). ${ }^{54}$ A reviewer for the bestselling British newspaper the Sunday Dispatch declared that "the strike scenes are brilliantly done. Mr Hanley can handle crowds and suggest mass emotion with a sure touch," while the novelist Ethel Mannin announced that "the descriptions of the workers' conflicts with police and troops during what I can only assume - since no dates are indicated - to be the General Strike of 1926, are quite simply terrific." 55

What did become a focus of contemporary critique, however, was the novel's working-class character's use of language. Ralph Straus, writing for the Sunday Times, questioned: "How . . . is one to believe in workpeople who are made to speak all like university dons? I do not ask for a phonetic rendering of all that they say, but these grammatical orations strike a wholly wrong note. ${ }^{, 56}$ In a perceptive review for the London Mercury, Hanley's abandonment of "the picturesque support of grime, violence and slang" was seen as an attempt to challenge the traditions of modern realism as evinced by William Faulkner, Ernest Hemingway and others, by breaking "all the fashionable rules":

The saga of industrial areas and mean streets should be shocking in its squalor and despair. Grim navvies should hurtle past us, drunken sailors trip over our feet, prostitutes assail our ears with shrill obscenities. The customary pages of oaths, curses, descriptions of natural functions, agonies of disease and childbirth - all these have disappeared. Mr Hanley, in fact, approaches his theme with a restraint that is positively startling and leaves us in air. ${ }^{57}$

There is more to the style and aims of Hanley's narrative in The Furys than simply the publisher's pruning of the manuscript's slang and swear words as described in the editorial and revision process above. But part of the novel's "restraint" and "air" identified here is a product and manifestation of the textual negotiations between author and publisher in the 
translation of The Furys from typescript to published book. The toning down of workingclass characters' language in The Furys to placate the largely middle-class readers in the circulating libraries is a patent example of how the perceived tastes of the circulating library market affected the writing and production of novels in the first half of the twentieth century. In this case the supposed conservatism of one of the major groups of paying readerships in Britain, and the publisher and distributor's sense of the literary and aesthetic tastes of that readership clearly influenced what D.F. Mc Kenzie has described as "the human presence in any recorded text". 58

Published at 10s. 6d. in large crown octavo on February 4, 1935 (560 pages long), The Furys was a large and serious-looking book designed to impress booksellers and the more "discerning" library reader. The circulating libraries were notoriously reluctant to purchase 10s. 6d. books in great numbers due to the short circulatory value of contemporary fiction. In his contribution to The Book World in 1935 for instance, Richardson made a disparaging reference to the contemporary "vogue ... for the very long novel, which the library dislikes, because it is bulky and expensive ... my impression is that many borrowers return it unfinished." ${ }^{, 59}$ Nevertheless, the circulating libraries put in a good subscription (advance) order for The Furys, encouraged no doubt by the book's being chosen as a Book Guild Choice for February 1935. Raymond wrote to Hanley that the actual subscription sales for The Furys were as follows:

$\begin{array}{lcl}\text { Jackson } & 68 \\ \text { Mudies } & 36 \\ \text { Boots } & 50 \\ \text { Smith } & 75 & \\ \text { Simpkin } & 100 \quad \text { [Simpkin Marshall, wholesalers] } \\ \text { Times } & 75^{60}\end{array}$

An advance subscription order of just over 400 copies from these major libraries and retailers represented a modest success (as a comparison, the ordinary subscription orders from the major book-buyers for the work of a more popular contemporary author such as Vita Sackville-West (1892-1962) were around 100 copies each in advance of publication). In reply 
to Hanley's question about his own response to the initial reception of the novel at the beginning of March 1935, Raymond answered:

Are C\&W pleased about The Furys?... The answer is in the unhesitating and unqualified affirmative. I never expected it to be a bestseller - it is in many ways too good for that - but it has come well up to my expectations and is still going steadily; Boots re-ordered 100 to-day, which brings the total to well over $2000 \ldots$. . This seems to me a very useful sale for a $10 / 6$ book. ${ }^{61}$

Records in the publisher's archive indicate that in the first two months of sales (up to the end of the financial year, March 31, 1935), 2715 copies of The Furys were accounted for. 1226 copies had been sold at the larger discounted price of 6s. 8d. to British libraries, wholesalers and bookshops, and a smaller number, 613 copies, were sold at the smaller discount of $7 \mathrm{~s}$. 345 copies of the book were sold at a further discount to the colonies. ${ }^{62}$ These early sales figures indicated that The Furys would do well.

Chatto \& Windus's cautious approach to the content and language of The Furys had, however, not been misjudged. Towards the end of 1934 while the book was at the printers, Hanley was caught up in a public obscenity case when copies of Boriswood's cheap 1934 edition of Boy were seized by the police from Bury Public Library. On January 17, 1935 the directors of Boriswood were summonsed for aiding and abetting the proprietor of the National Libraries in Manchester, George D. Franks, for publishing an obscene libel. ${ }^{63}$ Raymond pencilled in a note at the end of a letter to Hanley on January 31 which congratulated him for his success across the Atlantic with Macmillans: "Bad luck about Boy. A bit late in the day for the Puritans to be attacking it." ${ }^{64}$ The publishers and librarian were tried under common law rather than the Obscene Publications Act and pleaded guilty, both receiving hefty fines. In his examination of the prosecution of Boy, James Armstrong quotes a letter from Franks's solicitors in which they advised that a legal defence, even if he argued that he had distributed a book which he had not read, would not be successful:

[the subject matter of Boy] is strictly forbidden, relating as it mainly does with intimacy between members of the male sex. The language of the Book is extremely frank and indeed crude, thus displaying the Author's talent of reproducing vividly the thoughts and speech of a certain class of sea-faring men. This vividness of language is at once, in our view, the "strength" of the book and its own condemnation. ${ }^{65}$ 
It is precisely this "vividness" of working-class language that Chattos was concerned about. The trial of Boy underlined the difficulty for publisher and librarian with regards to obscene libel where, as Stanley Unwin pointed out, "there is no uniformity of punishment or practice. An offence which would cost a publisher $£ 10$ in Edinburgh, or $£ 100$ in London, may cost him $£ 400$ in Bury." was at stake for libraries with "Red Label" volumes and helps to explain some of their reluctance to circulate what was likely to prove controversial or morally questionable to the tastes of their readers.

As a result of the trial, Hanley joined the ranks of fellow controversial novelists like D.H. Lawrence and Radclyffe Hall, and in June 1935 he accompanied E.M. Forster to the International Congress of Writers for the Defence of Culture, where Forster spoke in defence of Boy. This kind of celebrity was however not to the taste of the average circulating library reader nor their cautious librarians. Sales of The Furys slumped dramatically after the prosecution of Boy. Chattos's Profit and Loss ledgers indicate that despite the promising uptake, only 75 further copies of The Furys were sold at a discounted price to libraries, bookshops and wholesalers by the end of March 1936 the following year, and only 86 to the colonies. Sales of Stoker Bush, published by Chattos in September 1935, and The Secret Journey, published in July 1936 (the second of the Furys pentalogy) were also slim, with only around 1000 copies in total going to the key British distributors of libraries, booksellers and wholesalers. Thinking of their four-book contract, the losses they were making on Hanley and with "a weather eye on our ledgers", Chattos urged him to turn to turn his attention "straight away to the autobiography and substitute that for volume three of The Furys in so far as the contract is concerned." ${ }^{, 67}$ Broken Water: An Autobiographical Excursion (1937) marked the end of Hanley's publishing relationship with Chattos. Again, sales at the libraries were relatively poor.

James Hanley was not, and never intended to be (neither according to himself nor his publisher) a successful library author, unlike contemporary writers published by Chattos including Ann Bridge or Margaret Irwin (1889-1969). Yet the concessions he was prepared to make in deference to the publisher's cautious appraisal of the circulating library market is suggestive of the impact of this readership and the purchasing practises of their head 
librarians on the publishing industry as a whole. A novel's successful circulation in the major circulating libraries like Boots in the first half of the twentieth century was important to its sales more generally; without the backing of private commercial libraries like Boots and Smith's, a novel's distribution - even a work not especially intended for their readership was likely to be limited. This particularly affected the innovative or challenging text as well as the potentially risqué. As the novelist Richard Aldington wrote to Chattos upon learning that Boots had finally agreed to circulate copies of his controversial World War One novel, Death of a Hero in October 1929: “Good indeed that Boots have at last 'come in'. Perhaps this will stimulate the others." 68

It is notoriously difficult to capture histories of reading. Scholars working in this field use a variety of tools to examine reading experiences and the habits of reading in the recent and historical past. As the editors of Palgrave Macmillan's recent three volume series on The History of Reading note, critics "use both macroanalytical (library surveys and publishing figures) and microanalytical (diaries and correspondence of individual readers) perspectives in their enquiry, and gather and interpret both qualitative (e.g. oral histories and entries in reading diaries) and quantitative (e.g. library circulation figures) data". ${ }^{69}$ This essay sits at a tangent to this new and emerging field. My interest here has been less with the reading experiences of the patrons of the Boots Book-lovers' Library per se, and more on how their large-scale borrowing habits and reading patterns impacted upon the fortunes and increasing stratification of the novel in this period. The literary influence of the Boots Book-lovers' Library readers may not be widely known, but a sense of their aesthetic tastes and needs as an audience clearly influenced the decisions made in publishing houses as well as writers' own appraisals of what they could do and achieve in their fiction, or otherwise. With so few remains of the reading patterns and borrower records of this vast, fee-paying readership surviving, the traces of their desires as can be found in glimpses of the production, revision, and censorship of novels such as James Hanley's The Furys are tantalising. That the continued influence of the commercial circulating library market on the history of the novel well into the twentieth century is not more broadly known skews our understanding of the production and reception of twentieth-century literature and its place in cultural history. Uncovering the impact of this audience in the records of publishers' archives may be one way to redress this.

Author's Note: This article is a product of the Arts and Humanities Research Council funded-project at the University of Reading UK, 'The impact of distribution and reading 
patterns on the novel in Britain, 1880-1940' (2008-12). I would like to thank Professor Patrick Parrinder and Dr Andrew Nash for their guidance throughout this project as well as the staff at the University of Reading Special Collections. I would also like to thank the Library History Round Table for awarding an earlier version of this essay the 2013 Justin Winsor Prize.

I am very grateful to Judith Wright at The Alliance Boots Archive \& Museum Collection, Nottingham, for allowing me access to the company archives and records, to staff at Westminster City Archives which houses the records of Bumpus Booksellers, and to Random House Publishers for access to the Chatto \& Windus files at Reading.

Permissions: Quotations of excerpts from unpublished letters by James Hanley are given with the permission of David Higham associates.

Images are reproduced with thanks to The Alliance Boots Archive \& Museum Collection, Nottingham.

\footnotetext{
${ }^{1}$ F.R. Richardson, "The Circulating Library,” in The Book World, ed. John Hampden (London: Nelson, 1935), 196.

${ }^{2}$ Stanley Unwin, "Introduction," in The Book World, ed. John Hampden (London: Nelson, 1935), 1-11 (11).

${ }^{3}$ Unwin, "Introduction," 10.

${ }^{4}$ James Hanley, The Furys (1935; Harmondsworth: Penguin, 1983).

${ }^{5}$ The classic study is Guinevere L. Griest, Mudie's Circulating Library and the Victorian Novel (Bloomington: Indiana University Press, 1970). For more recent work see for example Troy J. Bassnett, "Living on the Margin: George Bentley and the Economics of the Three-Volume Novel, 1865-70," Book History 13 (2010): 58-79.

${ }^{6}$ Peter Keating, The Haunted Study: A Social History of the English Novel 1875-1914 (London: Fontanta, 1991), 279-80.

${ }^{7}$ Nickianne Moody, "Fashionable Design and Good Service: The Spinster Librarians at Boots Booklovers Library," in Gendering Library History, eds. Evelyn Kerslake and Nickianne Moody (Liverpool: Liverpool John Moores University Press, 2000), 131.

8 "Boots Catalogue: Complete Periodical List", November 1920. Nottingham, The Alliance Boots Archive \& Museum Collection, Box 396.

${ }^{9}$ Harold Raymond to Margaret Monsell, January 6, 1937. University of Reading, Special Collections, Records of Chatto \& Windus Ltd (hereafter CW), CW A/179.

${ }^{10}$ F.R. Richardson, "Progression" in "Library Notes," The Bee, June 1922: 17.

${ }^{11}$ Sidney Dark, The New Reading Public. A lecture under the auspices of The Society of Bookmen (London: Allen \& Unwin, 1922), 5.

${ }^{12}$ Richardson, "The Circulating Library," 196.
} 
${ }^{13}$ B. Seebohm Rowntree and G.R. Lavers Longmans, English Life and Leisure: A Social Study (London: Longmans, 1951), 307.

${ }^{14}$ Nicola Beauman, A Very Great Profession: The Woman's Novel 1914-39 (1983; London: Persephone, 2008),

1. The second quote, quoted by Beauman, is from Noel Coward, Still Life (1935), in Plays: Three (London: Eyre Methuen, 1979), 348.

${ }^{15}$ Elizabeth Bowen, The Death of the Heart (1938; London: Vintage, 1998), 182.

${ }^{16}$ Bowen, Death of the Heart, 184.

${ }^{17}$ Mary Hammond, Reading, Publishing and the Formation of Literary Taste in England, 1880-1914 (Aldershot: Ashgate, 2006), 27-50. Center for Middletown Studies, Ball State University Libraries and Muncie Public Library, What Middletown Read, http://www.bsu.edu/libraries/wmr/about.php. As yet there are no entries on Boots in 'The Reading Experience Database, 1450-1950', http://www.open.ac.uk/Arts/RED/

18 "Our Customers," The Bee, April 1922: 11-12.

${ }^{19}$ According to the contributors to H.L. Beales and R.S Lambert's edited collection, Memoirs of the Unemployed (London: Gollancz, 1934), the weekly rent is typically between 7s. 6d. and 12s. 6d.

${ }^{20}$ Rowntree and Longmans, English Life, 307.

${ }^{21}$ George Moore, "A New Censorship of Literature" (1884), in Literature at Nurse, or Circulating Morals: A Polemic on Victorian Censorship, ed. Pierre Coustillas (Sussex: Harvester, 1976), 27-32.

${ }^{22}$ Publicity material, c.1950. Nottingham, The Alliance Boots Archive \& Museum Collection, Box 396/28.

${ }^{23}$ Publicity material, c.1939/40. Nottingham, The Alliance Boots Archive \& Museum Collection, Box 396/24.

${ }^{24}$ Moody, "Fashionable Design", 132.

${ }^{25}$ Boots Booklovers Library First Literary Course, "First Paper: Detective Stories and Thrillers," 8; "Fourth Paper: Light Romances and Family Stories and Westerns," 1. Nottingham, The Alliance Boots Archive \& Museum Collection, Box 460.

${ }^{26}$ Free Library Abingdon to Bumpus Booksellers, March 26, 1907. Westminster City Archives, Bumpus Booksellers, MS 418, Box 2.

${ }^{27}$ Society of Bookmen, Report of the Commercial Circulating Libraries Sub-Committee, etc. (London, 1928), 10 .

${ }^{28}$ Winifred Holtby, “What We Read and Why We Read It,” The Left Review, 1.4 (January 1935): 112.

${ }^{29}$ Q.D. Leavis, Fiction and the Reading Public (1932; Harmondsworth: Penguin, 1965), 21.

${ }^{30}$ See for instance Erica Brown and Mary Grover, ed., Middlebrow Literary Cultures: The Battle of the Brows, 1920-60 (New York: Palgrave Macmillan, 2012).

${ }^{31}$ Frank H. Woolley, “About Books,” The Bee, February 1922, 15.

${ }^{32}$ Richardson, "The Circulating Library," 200.

${ }^{33}$ For a discussion of Elizabeth Carfrae's popular appeal and the publisher's aggressive marketing of her work see Joseph McAleer, Passion's Fortune: The Story of Mills \& Boon (Oxford: Oxford University Press, 1999), 46, 49-52.

${ }^{34}$ Boots First Literary Course, "Tenth Paper: Best Sellers," 3-4. 
${ }^{35}$ On the development of some publishers as "library houses" in the interwar period see Joseph McAleer, Popular Reading and Publishing in Britain 1914-1950 (Oxford: Clarendon Press, 1992), 58. McAleer specifically relates this phenomenon to the demands of the commercial "Twopenny" market.

${ }^{36}$ Boots First Literary Course, "Ninth Paper: Publishers and Best Sellers”, appendix 2.

${ }^{37} \mathrm{CW}$ to Mary Desmond MacCarthy, January 23, 1918, CW A/92.

${ }^{38}$ Society of Bookmen, Report, 10.

${ }^{39}$ Percy Spalding to Mrs Fanny Emily Farr Penny, March 16, 1917, CW A/90.

${ }^{40}$ Boots First Literary Course, "Fourth Paper: Light Romances and Family Stories and Westerns," 4.

${ }^{41}$ Society of Bookmen, Report, 7.

${ }^{42}$ Revised Instructional Circular Letters, November 1951, 14. The Alliance Boots Archive \& Museum Collection, Box 460, D/W/55.

${ }^{43}$ I am grateful to John Fordham's book, James Hanley: Modernism and the Working Class (Cardiff: University of Wales Press, 2002) for some of the biographical information and details of publishing history in this section. ${ }^{44}$ This introduction is referred to in a letter from Richard Aldington to Charles Prentice, December 4, 1929, CW 48/3.

${ }^{45}$ Hanley to Raymond, January 8, 1935, CW 62/1, folder 2.

${ }^{46}$ Mawson Swan and Morgan to Raymond, January 12, 1935; Alan Steele to Raymond, January 11, 1935; F.R. Richardson to Raymond, January 10, 1935; CW 62/1.

${ }^{47}$ Raymond to Hanley, July 11, 1934, CW A/158.

${ }^{48}$ Hanley to Raymond, July 12, 1934, CW 52/3.

${ }^{49}$ Raymond to Hanley, July 11, 1934, CW A/158.

${ }^{50}$ Raymond to Hanley, July 13, 1934, CW A/158.

${ }^{51}$ Hanley to Raymond, July 18, 1934, CW 52/3.

${ }^{52}$ Hanley, The Furys, 248.

${ }^{53}$ Copies of Boy and The German Prisoner were seized by the police and destroyed in March and October 1935. See James Armstrong, “The Publication, Prosecution, and Re-publication of James Hanley’s Boy (1931),” The Library: A Quarterly Journal of Bibliography, 6.14 (1997): 352-62, 357.

${ }^{54}$ Daily Herald, February 7, 1935, clipping in CW Newspaper / Reviews Book, vol. 52 (1935), 51. The literary comparisons are made by James Agate in his highly critical review for the Daily Express, February 7, 1935, in CW Reviews Book, 58.

${ }^{55}$ Sunday Dispatch, February 6, 1935, in CW Reviews Book, 50; Ethel Mannin, "Books to Interest the Working Class," New Leader, February 28, 1935, in CW Reviews Book, 58.

${ }^{56}$ Ralph Straus, “Working Class Saga,” Sunday Times, February 3, 1935, in CW Reviews Book, 51.

${ }^{57}$ A.C., London Mercury, March 1935, in CW Reviews Book, 59.

${ }^{58}$ D.F. McKenzie, 'The Book as an Expressive Form' (1985), in The Book History Reader, ed. David Finkelstein and Alistair McCleery (London: Routledge, 2002), 37.

${ }^{59}$ Richardson, "The Circulating Library," 199.

${ }^{60}$ Raymond to Hanley, March 29, 1935, CW 62/1, folder 2.

${ }^{61}$ Raymond to Hanley, March 4, 1935, CW 62/1, folder 2. 
${ }^{62}$ In the Chatto \& Windus Profit and Loss ledgers for this period the two largest sales figures for individual titles (excluding where a Book Society nomination is recorded) represent the publishers' discount given to British libraries, bookshops and wholesalers. Customers would receive a larger or smaller discount depending on how many copies of a book they ordered in bulk. For a 10/6 book like The Furys the discounted price offered to libraries, bookshops and wholesalers was either $6 / 8$ or 7/-. For a 7/6 book the discounted price was $4 / 9$ on larger orders or 5/- on smaller orders. The third largest sales figure in the ledgers normally represents sales to the colonies, which received an additional discount from the publisher (this was normally $5 / 3$ on a 10/6 book and $3 / 3$ on a $7 / 6$ book).

${ }^{63}$ Armstrong, 354.

${ }^{64}$ Raymond to Hanley, January 31, 1935, CW 62/1, folder 2.

${ }^{65}$ Neville Isitt \& Co. to the National Libraries, 3 December 1934. Harry Ransom Humanities Research Center, The University of Texas at Austin, Boriswood Ltd archive; quoted in Armstrong, 354.

${ }^{66}$ Stanley Unwin, The Truth about Publishing, fourth edition (London: Allen \& Unwin, 1946), 94-5.

${ }^{67}$ Raymond to Hanley, February 1, 1937, CW A/180.

${ }^{68}$ Richard Aldington to Raymond, October 28, 1929, CW 48/3.

${ }^{69}$ Shafquat Towheed and W. R. Owens, "Introduction", in The History of Reading. Volume 1, International

Perspectives, c. 1500-1990, eds. Shafquat Towheed and W. R. Owens (Houndmills: Palgrave Macmillan, 2011), 3. 